\author{
A Hall for Hercules at Ostia and a Farewell to the Late Antique "Pagan Revival" \\ Author(s): DOUGLAS R. BOIN \\ Source: American Journal of Archaeology, Vol. 114, No. 2 (April 2010), pp. 253-266 \\ Published by: Archaeological Institute of America \\ Stable URL: http://www.jstor.org/stable/25684274 \\ Accessed: 02-06-2015 18:57 UTC
}

Your use of the JSTOR archive indicates your acceptance of the Terms \& Conditions of Use, available at http://www.jstor.org/page/ info/about/policies/terms.jsp

JSTOR is a not-for-profit service that helps scholars, researchers, and students discover, use, and build upon a wide range of content in a trusted digital archive. We use information technology and tools to increase productivity and facilitate new forms of scholarship. For more information about JSTOR, please contact support@jstor.org. 


\title{
A Hall for Hercules at Ostia and a Farewell to the Late Antique "Pagan Revival"
}

\author{
DOUGLAS R. BOIN
}

\begin{abstract}
In 1945, Herbert Bloch published an inscription from Ostia recording the restoration of a cellam Herc[ulis] in the late fourth century and suggested that it heralded the last pagan revival in the western Roman empire. Social historians now largely dispute this thesis, yet the details of the Ostian evidence remain unchallenged. This article demonstrates that the Hercules inscription, which Bloch attributed to the so-called Temple of Hercules (1.15.5) at Ostia, more probably records the restoration of a bath complex once decorated with the labors of Hercules. Given the persistence of traditional religious practices now known to have characterized the Late Antique city, neither the restoration of the baths nor the temple need bear the weight of religious revivalism. Evidence suggests that the urban image of fourth-century Ostia remained inconspicuously traditional, even as Christianity gained a more visible presence in the town.*
\end{abstract}

\section{INTRODUCTION}

In 1945, Herbert Bloch published an article that has had a lasting influence on Late Antique social history. It purports to describe a "pagan revival" operating in Rome and Ostia at the end of the fourth century. By funding and, more importantly, advertising the restoration of an ancient temple of Hercules at Ostia, the sponsors of the restoration were attempting to influence public opinion, casting themselves as a formidable opposition party to the ruling Christian factions. ${ }^{1}$ According to Bloch's interpretation, in 393-394 C.E.

\footnotetext{
* This study was made possible with the support of the University of Texas at Austin, which awarded me a University Continuing Fellowship in 2007-2008 to conduct research in Rome. I owe particular thanks to the Institute for the Study of Antiquity and Christian Origins in the Department of Classics at the University of Texas and to its director, L. Michael White. The Soprintendenza per i Beni Archeologici di Ostia ad interim, Angelo Bottini and Margerita Bedello, kindly permitted me to conduct this research on-site during July and August 2006; and I would like to thank the archaeological director at the time, Angelo Pellegrino, for permission to conduct further study in the fall of 2007. The logistical assistance provided by Paola Germoni was invaluable, as was the help of Elvira Angeloni. My thanks to the library staff of the American Academy in Rome and the British School at Rome for their assistance. I would also like to acknowledge Editor-in-Chief Naomi J. Norman and the anonymous reviewers for the AJA for their constructive suggestions. The following individuals
}

the members of that "pagan revival" rallied around $\mathrm{Eu}$ genius' claim to the western empire. For his own part, Eugenius was preparing an army to attack the emperor Theodosius. In 394 at the Frigidus River, on the border between Italy and modern Slovenia, Theodosius defeated the imperial usurper. ${ }^{2}$ Calling the Ostian inscription a "new document" in " $[t]$ he final phase of this struggle," Bloch framed his discussion of it in light of archaeological evidence suggesting the Temple of Hercules was the most historic sacred monument at the old harbor of Rome. In particular, he proposed that the temple was a fitting and powerful architectural symbol for a "pagan party" eager to establish the cultural force of its own historic roots. ${ }^{3}$

Since Bloch's article first appeared, however, and especially in the aftermath of its republication in 1963, social and cultural historians have cast an increasingly skeptical eye on the concept of a "pagan revival," preferring to interpret the fourth century as a period of accommodation and acculturation, not one of hostile citywide conflict. ${ }^{4}$ Some scholars, although not all, now eschew the terms "pagan" and "paganism" altogether. As words wielded by confrontational Christians eager to describe the backward nature of their neighbors who refused to convert to the new religion, these words often functioned as quick and easy slurs for a minority that disapproved of mainstream culture, particularly during the fourth century. ${ }^{5}$ Given this recent research,

deserve mention for the insight and conversation they provided:Jan Theo Bakker, Alan Cameron, Penelope Davies, Jen Ebbeler, Karl Galinsky, Genevieve Gessert, Glenn Peers, Adam Rabinowitz, Michele Salzman, Joanne Spurza, Rabun Taylor, Dennis Trout. A preliminary version of this article was delivered at the annual meeting of the Archaeological Institute of America in Chicago in January 2008 and again in Rome at the International Meeting of the Society of Biblical Literature in July 2009. Any errors that remain are my own. All translations are by the author unless otherwise noted.

${ }^{1}$ Bloch 1945; see also Bloch 1963.

${ }^{2}$ For narrative introductions to this historical period, see Jones 1966; see also Cameron 1993, 66-84.

${ }^{3}$ Bloch 1945, 202.

${ }^{4}$ Briefly, e.g., see Salzman 1990, 193-246; see also Cameron 1999; Drake 2000, 246-47; Hedrick 2000, 47-54.

${ }^{5}$ Most recently, O’Donnell 2005, 182-90. For more detailed discussion, see also O'Donnell 1977, 165-68. 
it is not surprising that the force of Bloch's general argument has already been diminished. Nevertheless, basic assumptions about the Ostian evidence have remained unchallenged. The Late Antique inscription referring to the restoration of a temple of Hercules is one such piece of evidence.

This essay offers a new study of that "document" in light of 60 years of epigraphic, architectural, and archaeological research undertaken at Ostia. Specifically, I propose that the inscription previously used to construct a narrative of "pagan revival" may not have had any connection to a temple or sanctuary space at all. It more likely came from an imperial bath complex, thereby enhancing our appreciation for the kinds of architectural projects undertaken in the late fourth-century city. Consequently, the Late Roman architectural repairs observed in the so-called Temple of Hercules at Ostia, a building intervention long coupled with the Hercules inscription, now demand interpretation on their own terms. In fact, as I show, the architectural repairs at this sanctuary, which is the oldest at Ostia, were hardly exceptional in an urban environment where monuments of traditional Roman religion remained both important centers of activity and places of memory throughout the fourth century. Although none of this data denies that Christianity was simultaneously gaining a more visible presence throughout the town, religious "revivalism," nevertheless, can no longer be a sole or sufficient motive for Eugenius' late fourth-century revolt.

OSTIA, $193^{8-1} 945$

Excavating the City

In the early decades of the 20th century, excavators such as Vaglieri, Calza, Becatti, and others were in the midst of dramatically changing the face of Ostia Antica, unearthing new regions of the ancient harbor of Rome. ${ }^{6}$ With the growing reality of war emerging on the Italian home front, this citywide campaign of excavation soon came to an end, although not before bringing some startling discoveries to light. It was in

${ }^{6}$ On Vaglieri’s efforts, see Olivanti 2002. On Calza and Becatti, see infra n. 9.

${ }^{7}$ Ostia, Museo Ostiense, inv. no. 121 (Picard 1976, 12324).

8 "Deo invicto Herculi Hostilius Antipater v(ir) p(erfectissimus) prae(fectus) ann(onae) curat(or) rei public(ae) Ost(iensium)" (AÉpigr 1948, no. 126).

${ }^{9}$ Calza 1938, 606-7; see also Becatti 1938-1939, 38.

${ }^{10}$ For a more thorough study of the opus incertum (first century B.C.E.) and opus latericium (second century C.E.) masonry, see Calza 1954, 106; see also Heres 1982, 422-24.

${ }^{11}$ Rieger 2001; 2004, 225-31; see also Mar 1990, 141-43; 1992, 172-81.
1938, for example, that Calza and Becatti discovered the large republican temple at 1.15 .5 (fig. 1) and its sanctuary area (fig. 2).

On the podium of the temple, the excavators discovered both a statue dedicated by an Ostian notable, G. Cartilius Poplicola, and a marble altar dedicated to Hercules. Picard, citing numismatic examples from Lyon, Sicily, and Rome, has now demonstrated that the statue, ${ }^{7}$ with one foot raised on a pedestal, represents an image of the genius of the town. At the moment of discovery, however, it was the inscribed altar that attracted more attention (fig. 3). The inscription reads, "Hostilius Antipater, vir perfectissimus, prefect of the grain-supply and curator of the town of Ostia [erected this altar] for Hercules, the Unconquered God." According to Calza, the altar was found "in situ on the porch" and thus confirmed the site as the seat of Hercules' cult. ${ }^{9}$

Becatti, who analyzed the masonry of the temple walls, revealed that it had initially been constructed in the first half of the first century B.C.E. ${ }^{10}$ Scholars still support Becatti's analysis of the masonry with only slight modification, extending the probable date of its construction to include the last decades of the second century B.C.E. ${ }^{11}$ Thus, the temple at 1.15 .5 , whose attribution to Hercules no one has ever questioned, is the oldest known temple at Ostia. Not surprisingly, its role in the development of the town remained a central one, and brick stamps testify that it was restored in the early second century C.E. ${ }^{12}$ Heres has even identified traces of a late fourth-century or early fifth-century restoration in its south wall. ${ }^{13}$

\section{The Late Antique Hercules Inscription}

Eight years after the initial publication of the temple at 1.15.5, Bloch published an inscription commemorating the restoration at Ostia of a cellam Herc [ulis]. ${ }^{14}$ “On September 16, 19 and October 15, 1938," Bloch wrote, "[three] fragments of a marble inscription were found in excavating the continuation of the via degli Horrea Epagathiana, near the so-called Pantheon, and

\footnotetext{
${ }^{12}$ Bloch dated brick stamps found in the opus latericium masonry to 110-112 C.E. (Calza 1954, 219) based on a comparison with Trajanic stamps known from Rome (CIL 15 23, 15 $60,15313)$. Heres (1982) modifies slightly Bloch's range of dates to include the years 102-112 C.E., although it is unclear whether she is basing her modification on new evidence or whether this is a typographical error. I suspect the latter: e.g., her reference to the brickstamp that Bloch found underneath the temple floor reads, "C.I.L.XV, 1054b" (Heres 1982, 422), an entry in CIL that does not exist (see Bloch 1945, 200 n. 6).

${ }^{13}$ Heres 1982, 422-24.

${ }^{14}$ AÉpigr 1941, no. 66; 1948, no. 127.
} 


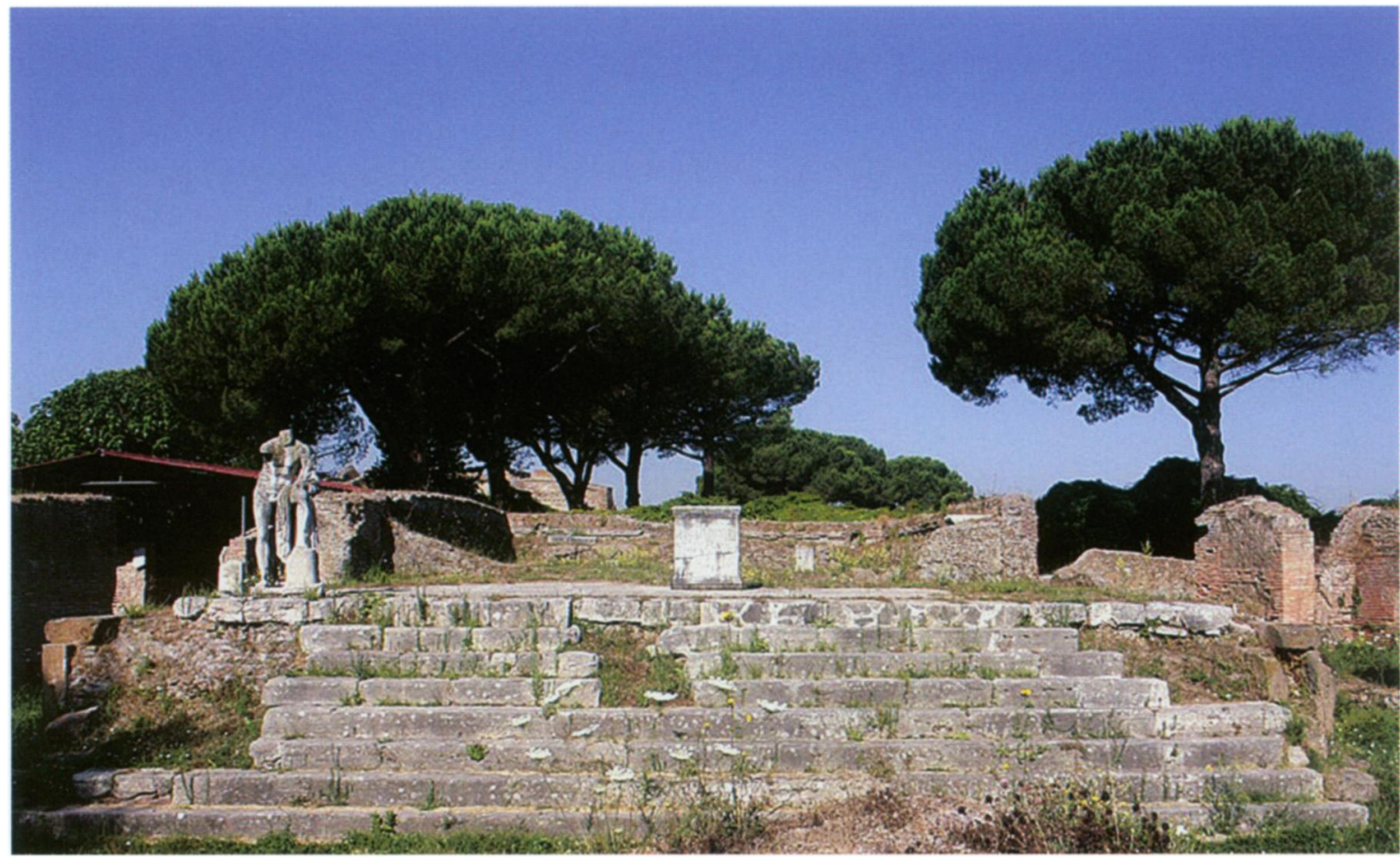

Fig. 1. The so-called Temple of Hercules, 2006.

not far from the Temple of Hercules." ${ }^{15}$ This inscription reads:

[Domini]s n[ostris Th] eodosio Arca[di]o et Eu[genio] [pi] is felicibus [toto] orbe victoribus semper [Aug(ustis)][. . ] Numerius Proiect [us v(ir) c(larissimus) pra] ef(ectus) ann(onae) cellam Hercu[lis restituit]

To our masters, Theodosius, Arcadius, and Eugenius, forever pious [ $p i i]$, blessed emperors [Augusti], victors over the whole world, Numerius Proiectus, vir clarissimus and Prefect of the Grain, restored the cellam of Hercules.

The mention of Eugenius, whose co-rule lasted from 392 to 394 C.E., provides a two-year window during which the inscription was erected.${ }^{16}$ Bloch himself immediately identified the cellam Hercu[lis] with the Temple of Hercules nearby. With the most ancient republican temple at Ostia recently attributed to this god and the Late Antique inscription demanding interpretation, two important pieces of the "pagan revival" had fallen into place. It was this inscription that Bloch used to construct his argument for a Late

\footnotetext{
${ }^{15}$ Bloch 1945, 201; see also Heres 1982, 422.

${ }^{16}$ Seeck 1919, 280-84; see also Jones et al. 1971, s.v. "Proiectus 1."
}

Antique "pagan party" active at Ostia at the end of the fourth century. ${ }^{17}$

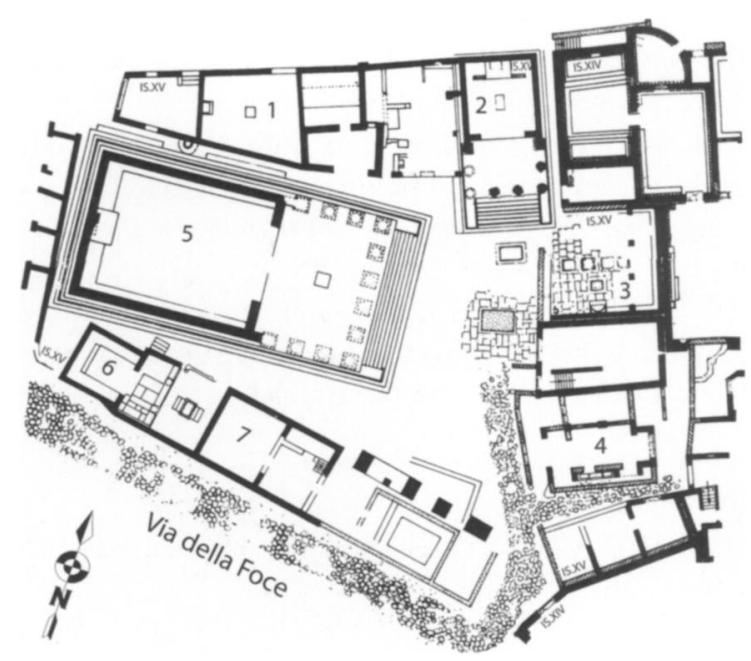

Fig. 2. Plan of the sanctuary at 1.15 .5 (adapted from Calza 1954, pls. 2, 7; courtesy Istituto Poligrafico e Zecca dello Stato, Rome).

\footnotetext{
${ }^{17}$ Not, pace Brenk $(2005,28)$, the Hostilius Antipater altar found on the temple porch.
} 


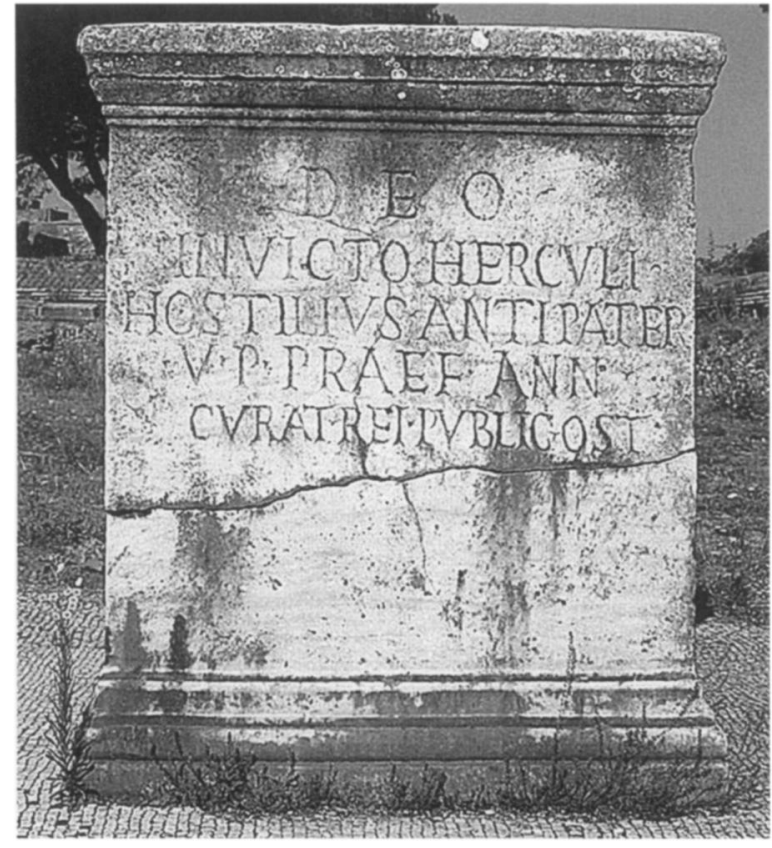

Fig. 3. Detail of the Hostilius Antipater altar, 2006.

\section{REVIEWING THE FOURTH-CENTURY NARRATIVE}

In hindsight, it is quite understandable why Bloch chose to view the moment of Eugenius' revolt through the lens of religious conflict. At the time of his article, many scholars cited Macrobius' Saturnalia as evidence for the existence of a powerful "pagan party." This party represented "the last Romans" who were engaged in a final valiant stand against Christianity at the end

\footnotetext{
${ }^{18}$ Bloch 1945, 203-8; see also Cameron 1999, 120-21.

${ }^{19}$ Jones et al. 1971, s.v. "Praetextatus 1."

${ }^{20}$ In part, the lack of any reference to Macrobius or to his work in the voluminous correspondence of $Q$. Aurelius Symmachus, one of the protagonists featured in the dialogue, suggested to Cameron $(1966,33-4)$ that the Saturnalia was the product of a later time, not contemporary with the setting of the dialogue. Philologically, Cameron also questioned the assumption that Jerome's letters (from 393-406 C.E.) contained references to the Saturnalia. According to Cameron (1966, 27-8), Jerome's textual sources for a discussion of medicine and the magical-philosophical use of numbers were, more likely, Plato and Galen, not Macrobius.

${ }^{21}$ Drake (2000, 20-32, 70-114, 192-231, 245-50) has interpreted the text of the so-called Edict of Milan as a savy diplomatic maneuver whereby the emperor used a policy of outreach to persecuted Christians to forge a more stable state. For the text of the so-called edict, preserved only in proChristian secondhand sources, see Euseb. Hist. eccl. 10.5.2-14 (Greek) (Croke and Harries 1982, 13-14); Lactant. De mort. pers. 48.1-12 (Latin). Lactantius (De mort. pers. 48.2) writes: "ut daremus et Christianis et omnibus liberam potestatem
}

of the fourth century. ${ }^{18}$ Indeed, Macrobius' text, the events of which are set shortly before the death of Vettius Agorius Praetextatus in 384 C.E., does present an impassioned defense of traditional Graeco-Roman religion. Earlier scholars, however, including Bloch, considered the dialogue a piece of direct testimony about the decades preceding Eugenius' attempted coup. ${ }^{19}$ In 1966, Alan Cameron challenged that longaccepted view and relocated the date of its composition to the 430s, divorcing the time of its writing from the time of its purported setting and thereby reframing the significance of the dialogue. ${ }^{20}$ Without the benefit of Cameron's analysis, Bloch built his case on the assumption that the Saturnalia offered a faithful reflection of late fourth-century society.

Decades later, our understanding of fourth-century society continues to change. Whether the topic is the social effects of Constantine's "conversion,"21 the brief reign of Julian, ${ }^{22}$ Gratian's removal of the Altar of Victory from the curia, ${ }^{23}$ or Theodosius' proscriptive Nicene Christianity legislation, ${ }^{24}$ contemporary scholarship has diminished the wider impact of these "canonical" events, the building blocks frequently used to construct a historical narrative dominated by religious confrontations. Consequently, the range and tenor of current scholarship now suggests that a "conflict model" of social relations between Christians and followers of the traditional religions at Rome is a difficult proposition to sustain for the fourth century. In light of this research, the Ostian evidence that once held a privileged position in the construction of a late fourth-century "pagan revival" now demands its own more contextualized approach.

sequendi religionem quam quisque voluisset." For other discussions of early fourth-century culture, see Elsner (2000, 163-67) and essays in Lenski 2006, 111-36, 159-82.

${ }^{22}$ On Julian's superstitio, see Amm. Marc. 22.12.6, 25.4.17; see also Matthews $1989,81-114$. Bowersock $(1978,79-93)$ is keen to point out that Julian's overt concern for the public appearance of temples and his desire to reinstitute animal sacrifice are issues specifically limited to the eastern regions of the empire, not the west, where urban temples and shrines continued to stand; see also Bradbury 1995, 347-55.

${ }^{23}$ As McLynn and Sogno have shown, the literary sources pertaining to the removal of the Altar of Victory are themselves more reflective of the ideologies of the parties involved than they are unbiased documents of a purported fourthcentury"conflict" (McLynn 1994, 166-67; see alsoSogno 2006, 45-54; Ebbeler and Sogno 2007, 240-41).

${ }^{24}$ Cod. Theod. 16.1.2 (28 February 380 C.E., addressed specifically to the people of Constantinople). Administrative details, such as the geographic origin of a decree, the name of the imperial official to whom it was addressed, and the place it was received, often vary from law to law. Any one of them may have affected its promulgation (Matthews 2000, 280-93). 
Contextualizing the Ostian Evidence in the FourthCentury Narrative

Since the time of Paschetto, who wrote the first historical narrative of Ostia in 1912, two assumptionsone historical, the other cultural-have often stymied an impartial study of the town in late antiquity. ${ }^{25}$ The first, based on the scant material evidence available at the time, presumed that signs of life at Ostia had substantially vanished by the end of the fourth century. The second, based on the construction of more visibly Christian architecture in cities such as Rome, beginning in the fourth century, characterized this same time as the period of purported Christian triumph, during which the increasing Christian presence paralleled a decreasing concern for traditional cults, temples, and even city spaces. Both assumptions have been effectively challenged in the last quarter of the 20th century.

It is now known, for example, that the occupation of urban and suburban Ostia continued throughout the fifth, sixth, and seventh centuries, even as the built environment of the city and its social fabric were being transformed from working-class harbor to luxury resort. ${ }^{26}$ This period, in particular, witnessed the transformation of several Ostian apartment complexes into sites of elaborately decorated Late Antique houses. ${ }^{27}$ City changes were not limited to domestic architecture, however. Between the third and fifth centuries, numerous shop fronts, major thoroughfares, and city squares in every region of the city became the focus of architectural revitalization. ${ }^{28}$ Fragments of evidence from across the site suggest that the senatorial elite was a driving force behind these urban transformations. In Region III near the mouth of the Tiber, for instance, a lead pipe bearing the names of two prominent Romans, Clodius Adelphius and Faltonia Proba (330-350 C.E.), was discovered in situ in the substructure of a private bath complex; a nearby road revealed traces of occupation in the sixth or seventh century. ${ }^{29}$

\footnotetext{
${ }^{25}$ Paschetto 1912, 83-4.

${ }^{26}$ Paroli 1993.

${ }^{27}$ Tione 1999; see also Muntasser 2003.

${ }^{28}$ Gering 2004. Lavan and Gering (2009) have recently designed a project to explore this topic. On Ostia's forum in late antiquity, see also Boin 2009, 29-43.

${ }^{29}$ Heinzelmann 2001, 324-25.

${ }^{30}$ Heinzelmann 2002, 235.

${ }^{31}$ Meneghini 2003, 1049-50. This overview is not meant to be comprehensive. The topography of Late Antique Rome and its traditional religious buildings is just beginning to emerge (Bauer 1996, 8-141). Some cult areas, such as the Iseum in the Campus Martius, are now known to have remained centers of activity into the fifth century (Ensoli and La Rocca 2000, 281). The study of Late Antique statuary plays an increasingly important role in this discussion of traditional reli-
}

Elsewhere, on the site of an Early Imperial villa in Region IV, recent excavations have discovered areas that were adapted for reuse during the late fourth and fifth centuries. ${ }^{30}$ All these findings suggest that care for the urban image of Ostia remained an important concern in late antiquity.

Perhaps as a result, this research has generated an appreciation for both the longevity and continued visibility of traditional religious practices during the same period. Archaeological surveys of neighboring Rome, for example, have recently confirmed an image of fourth-century temple architecture hardly in need of restoration. ${ }^{31}$ Salzman, through an analysis of the fourth-century festival calendar, has similarly revealed no discernible transformation in religious practices in the capital during the same time. ${ }^{32}$ The evidence from Ostia, in fact, dovetails nicely with this picture of resilient religious architecture and abiding social practices in Rome. ${ }^{33}$ In 359 C.E., for example, during a period of rough winds, the urban prefect of Rome initiated a procession to the Temple of Castor and Pollux at Ostia to ensure the safe landing of the grain fleet at Portus. ${ }^{34}$ Less than two decades later, it is known that the prefect of the grain on the orders of the emperors-Valens, Gratian, and Valentinian II-financed the restoration of the temple and porticus of Isis (375-378 C.E.).$^{35}$ At some point between 360 and 390 C.E., moreover, the prefect of the city of Rome, a man named Volusianus, dedicated a statue commemorating his taurobolium at the Sanctuary of Magna Mater. ${ }^{36}$ Meanwhile, throughout the fourth and fifth centuries, it is highly likely that Vulcan, the patron god of Ostia, continued to receive games and celebrations. ${ }^{37}$ The tenacity of these traditional religious displays at Ostia during a century often described exclusively in terms of the spread of Christianity thus belies any notion of Christian "triumph" in the decades predating Eugenius' late fourth-century revolt.

gious vitality; see also Bauer and Witschel 2007.

${ }^{32}$ Salzman 1990, 227-31

${ }^{33}$ Like the sketch of traditional religious practices and architectural restoration offered for Rome in this article, the treatment of Late Antique Ostia here does not aim to be comprehensive. See Boin (2009, 116-23) for further discussion and bibliography. For the long-lasting nature of religious devotion in the households at Ostia, including a discussion of Mithraism, see Bakker 1994, 178-94.

${ }^{34}$ Amm. Marc. 19.10.4; Boin 2007.

${ }^{35}$ AÉpigr 1961, no. 152.

${ }^{36}$ Ostia, Museo Ostiense, inv. no. 165 (Rieger 2004, 287; Boin 2009, 104-11).

${ }^{37}$ CIL 1(2) 332 (354 C.E.); see also CIL 1(2) 349 (448-49 C.E.). For a discussion by Degrassi, see II 13(2):500-1, s.v. “Aug. 23." For Vulcan as Ostia's patron god, see infra n. 41. 
OSTIA REDUX, 1938-1945

The So-Called Temple of Hercules

The time is right, therefore, to reconsider the content and the context of the Late Antique Hercules inscription. Although my primary concern is to offer a new reading of the text, it is worthwhile, nonetheless, to begin by discussing the archaeological circumstances of the discovery itself. None of the three fragments of the Hercules inscription was found within the sanctuary at 1.15.5, now known as the Sanctuary of Hercules. Rather, they were unearthed on a "continuation of the via degli Horrea Epagathiana, near the so-called Pantheon," 38 the latter name signifying the "Round Temple" near the forum (fig. 4). Bloch may have chosen to claim that the findspot was "not far from the Temple of Hercules," but his casual lack of specificity belies an important point. ${ }^{39}$ The inscription was only associated with the temple at 1.15 .5 after Calza had proposed identifying it with the cult of Hercules..$^{40}$ This detail is significant because even the association of the large temple at 1.15 .5 with Hercules is far from certain. ${ }^{41}$

At the time of the discovery of the sanctuary, Calza and, later, Becatti each expressed surprise at such a large temple dedicated to Hercules at Ostia. In fact, any indication that Hercules had played a significant role in the religious life of the city had been relatively scarce until then, especially in contrast to the situation at Rome. ${ }^{42}$ The only evidence from the archaeological record was a few wall paintings, some small statuettes, an occasional epigraphic reference, and one or two terracotta lamps. ${ }^{43}$ Moreover, from the time of the foundation of Ostia to its Late Antique period, there was no reference to a temple of Hercules in any epigraphic or other textual source. Nothing mentioned the construction of such a building or its dedication

\footnotetext{
${ }^{38}$ Bloch 1945, 201 (emphasis original).

${ }^{39}$ Bloch 1945, 201.

${ }^{40} \mathrm{~A}$ similar, although perhaps misguided, urge to "repatriate" other Hercules material explains why the altar (CIL 14 4280) discovered in the Casa di Diana (1.3.3-4) is now displayed on-site. Its inscription reads, "aqua salvia | Herculi sacr(um)" (Becatti 1942, 120). A second inscription also currently on display reads, "P. Livius P. L. Her. dat." I can find no evidence that it was ever formally published. Neither Calza nor Becatti make any mention of it in their reports (Calza 1938; Becatti 1938-1939), nor does Becatti (1942) mention it in his follow-up article. As a result, its connection with the sanctuary at 1.15 .5 remains suspect. One could even argue, e.g., that "Her.," instead of denoting a dedication to Hercules, is an abbreviated form of the dedicator's cognomen.

${ }^{41}$ An equally persuasive case, e.g., could be made that the building was originally dedicated to Vulcan (Boin 2009, 5280). The Temple of Vulcan is a structure long missing but never found (Rose 1933; see also Meiggs 1973, 336-53). Vulcan
}

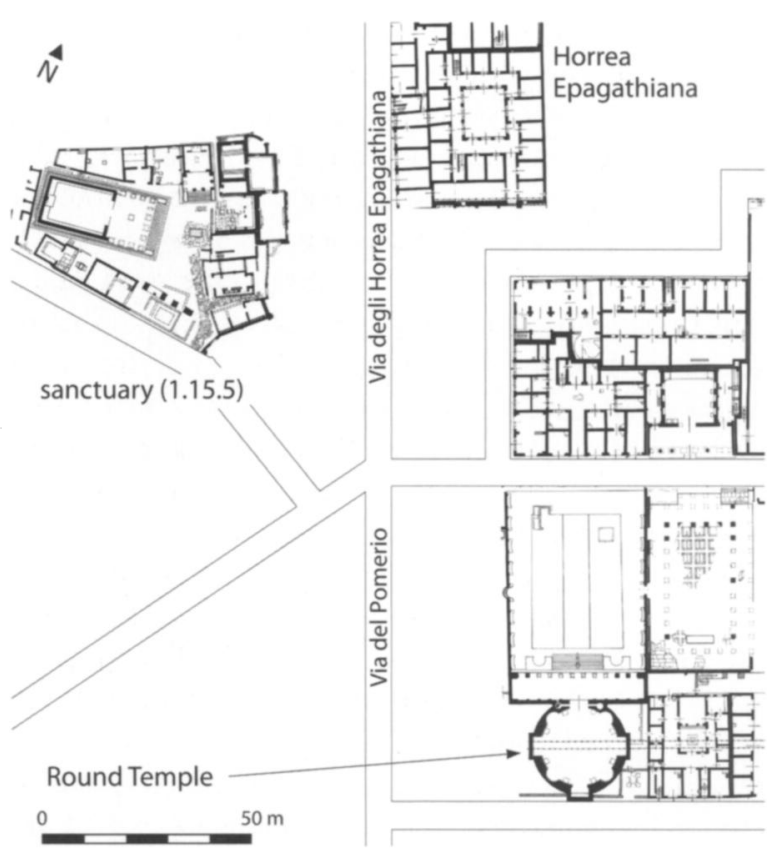

Fig. 4. Modified plan of Ostia's city center and the location of the Via degli Horrea Epagathiana (adapted from Calza 1954, pls. 2, 7; courtesy Istituto Poligrafico e Zecca dello Stato, Rome).

or its restoration. The town fasti were equally silent about any local festival in Hercules' honor.

Setting aside these broader details, there were additional signs that should have cautioned against assigning too prominent a significance to the discovery of the altar. Contrary to the claim that it had been found in situ, the porch floor had already been ripped up at the time of its discovery. ${ }^{44}$ Becatti himself wrote, "The large staircase of eight stairs was preserved in

was the "deus patrius" for Ostia (CIL 143). It was Vulcan's pontifex who held the authority over other religious buildings in the harbor town (CIL 14 72; see also CIL 14 132, 14 324-25, 14 352 ). The latest contribution to the ongoing search for Vulcan's temple is from Marchesini (2004-2005), who collects all the material evidence for Vulcan's cult at the harbor. My thanks to Grazia Pettinelli and the staff of the library at Ostia for bringing this work to my attention. The most recent proposal to identify the temple locates it within the curia (1.9.4) (Rieger 2001, 250; 2004, 219-25). Vitruvius and Plutarch, however, record that temples of Vulcan (Hephaistos) were frequently located outside city walls (Vitr. De arch. 1.7.1; see

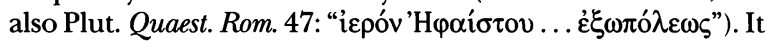
is worth noting that the temple at 1.15 .5 does lie outside the early castrum (Calza 1954, 63-78).

${ }^{42}$ E.g., on the cult of Hercules Victor and Hercules Invictus in early Rome, see Coarelli 1988, 78-106.

${ }^{43}$ Becatti 1938-1939, 37; see also Taylor 1912, 36-78.

${ }^{44}$ Calza 1938, 606-7. 
travertine throughout a great part, but there were no remains of the architectural elements of the porch or cella. And the complete and systematic despoiling [ $l a$ spoliazione completa e sistematica] of the porch and cella indicates the uses of marble, or at least travertine, for the columns and for the pavement [pavimentazione]." ${ }^{35}$ A photograph taken at the time of the excavation confirms that the altar was originally found sitting on mosaic and soil, not on an intact floor (fig. 5) ${ }^{46}$ Most of the mosaic on-site at present belongs entirely to a 20th-century restoration project; close inspection even reveals the presence of modern concrete underneath a broken corner of the altar slab (fig. 6).

I make this point not to impugn Calza's ability as an excavator but rather to show that the altar has been moved at least once in the modern era. Therefore, it is a questionable assumption that the altar remained on the porch of the oldest temple in the city for two millennia. ${ }^{47}$ Inscriptions and altars are notorious drifters. ${ }^{48}$ The Hercules altar may not be an exception. Even in the late third century C.E., the stone itself was already on its second life. Upside down and on the reverse is an earlier inscription from the time of Gallienus, when the marble altar had been used as a

\footnotetext{
${ }^{45}$ Becatti 1938-1939, 39.

${ }^{46}$ Additional photographs are available at the Soprintendenza di Ostia Antica, Archivio Fotografico, negs. C1130, B2728, B3338.

${ }^{47}$ Moreover, Calza's (1938) article is not a formal, scientific publication of the site but rather an effort to juxtapose contemporary excavations of Ostia with Mussolini's political campaign to glorify the republican heritage of Rome. As such, Calza's claim that the Hercules altar was found "in situ," a phrase Becatti himself never used when writing about the site, may be part of a broader effort to privilege, selectively and ideologically, the republican past of Ostia at the expense of any broader contextual reading of the evidence. E.g., even if we do accept a modified understanding of the term "in situ," the fact that the floor and columns of the porch had already been removed suggests we are beholding not a Republican period mise-en-scène but a much later one.

${ }^{48}$ Ostian marbles and inscriptions have migrated over time. A cippus from Ostia found its way to the cathedral of Pisa (CIL 149) and a dedication by an Ostian guild appears in the baptistery of San Giovanni in Florence (CIL 14 105); see also Meiggs 1973, 102-10; Bignamini 2001.

${ }^{49}$ Bloch $(1945,200-1)$ deduced a late third-century or possibly early fourth-century C.E. date based on the appearance (on one side of the marble) of the name P. Flavius Priscus, who served under the emperor Gallienus (d. 268 C.E.), and Hostilius Antipater's title, vir perfectissimus, an honorific that falls out of use in the first decades of the fourth century; see also Zevi 1971.

${ }^{50}$ As Laird $(2000,42-7)$ has now shown, there are often methodological hazards in assuming any relationship between a Roman object and its modern findspot at Ostia Antica, not the least of which is the plethora of medieval lime kilns located throughout the town, where sculptures were col-
}

statue base. ${ }^{49}$ Thus, considering the ruined state of the buildings around it, the complete despoliation of the columns and the porch, and the absence of any other dedications comparable in size at such an important cult center, the relevance of the altar to the identification of the large temple in the Late Republican sanctuary is tenuous at best. I would tentatively propose that its central placement on the ransacked porch suggests the presence at the site of much later antiquarians, eager to compose their idea of a classical scene and impose it on the ruined landscape. Whatever these circumstances, it would have been far safer to conclude in 1938 that the attribution of the large temple at 1.15.5 remained unclear.

Even today, seven decades since the time of its discovery, the sanctuary has yielded only one additional piece of evidence that may or may not have any bearing on the Roman cult once worshiped there.$^{50}$ Found in the area directly east of the temple, this lone object is a travertine relief depicting, at center, a bearded figure whose lion skin and club identify him as Hercules (fig. 7) ${ }^{51}$ Becatti believed that the bearded figure caught in the net, at right, depicted the same god ${ }^{52}$ he used the relief to construct a narrative affirming the

lected for melting down. Becatti himself thought that the relief did illuminate the cultic life of the sanctuary in which it was found (Becatti 1938-1939, 39; 1942).

${ }^{51}$ Ostia, Museo Ostiense, inv. no. 157 (Becatti 1938-1939). The relief measures $1.45 \times 0.71 \mathrm{~m}$, with an inscription carved above the figural panel that reads, "C•FULVIUS•SALVIS• HARUSPEXS $\cdot \mathrm{D} \cdot \mathrm{D}$." The text height is $5.0 \mathrm{~cm}$. Beneath this inscription, Becatti interpreted a three-part visual narrative, reading from right to left. The first scene (right) is a group of three fishermen, pulling their net and catches from the sea. Inside the net is a bearded male, seen in profile, facing left, and at bottom of the net, a rectangular chest. The second scene (center) is an interaction between a bearded male and a young man dressed in a toga. This bearded male, standing on the right of a plinth or open chest, hands the young man a rectangular object. Unfortunately, the third scene (left) is only partially preserved. A male in a toga, facing left, offers something with his outstretched hand. At his shoulder, a winged victory figure, facing away from the male, holds one side of a wreath.

${ }^{52}$ As Becatti (1938-1939, 40) makes clear, the iconography of Hercules, represented "in the act of an attack," with raised club and extended arm, holding a bow, is certainly well attested. I would suggest that the fishermen may not have found a statue of Hercules. First, the implement that the bearded figure holds in his outstretched right hand may not be a club. It is not tapered toward the handle, nor does it show the gnarled knots along its shaft. Instead, its handle is rather rectangular, and the blunt end, at least from what one can see before it disappears under the net, appears square. In short, it may be a hammer. From an iconographic perspective, it in no way resembles the club that the bearded man (center) balances against his shoulder with his left hand. 


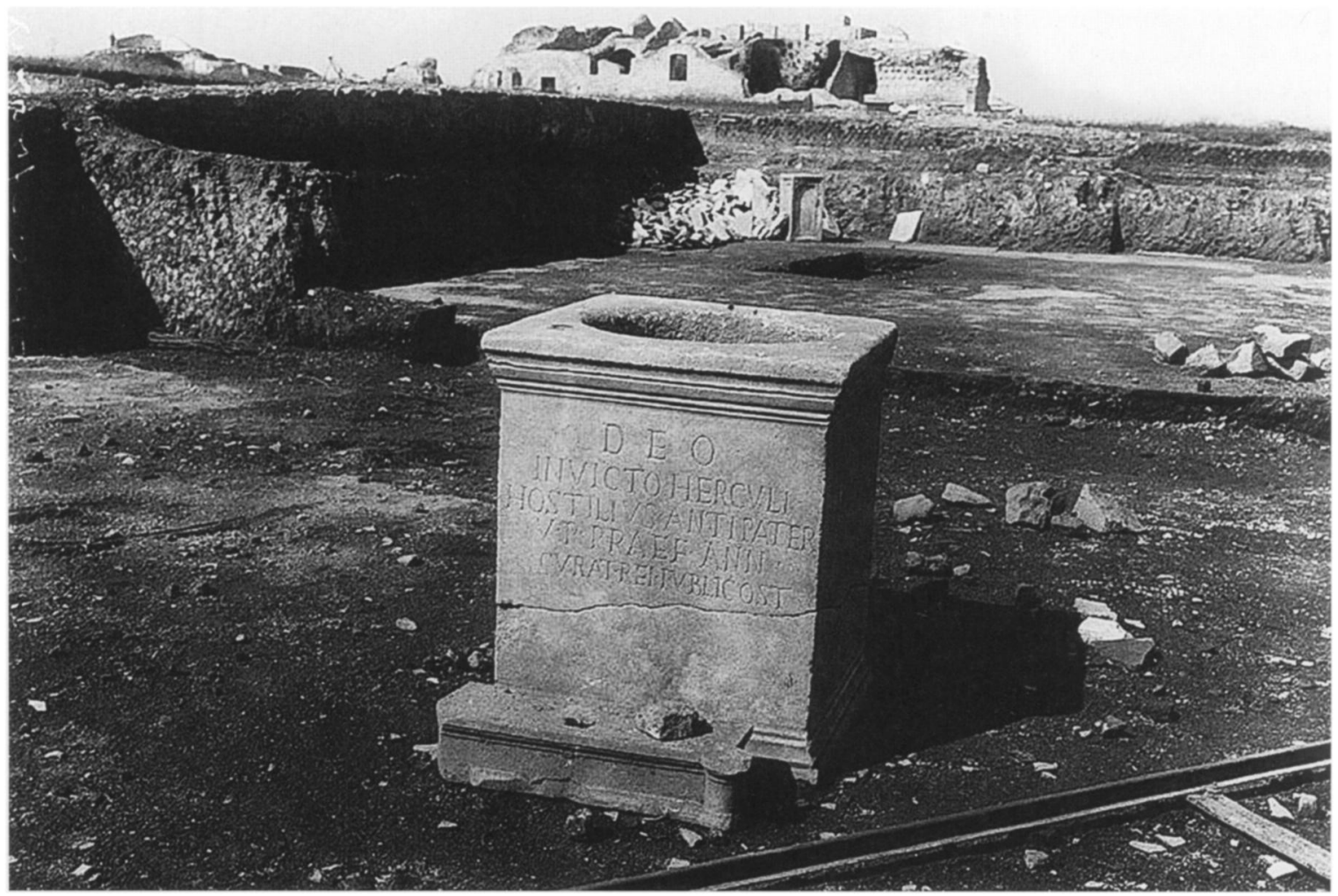

Fig. 5. The temple podium at the time of excavation, 1938 (courtesy Soprintendenza per i Beni Archeologici di Ostia, Archivio Fotografico, neg. B2627).

cultic importance of Hercules at Ostia..$^{53}$ The figure at the left, however, could be the god Vulcan; $;^{54}$ and the scene depicted there could represent a myth or an

\footnotetext{
${ }^{53}$ Becatti (1938-1939) posited that this "Temple of Hercules" had been an oracular shrine, a conclusion he based on the iconography of the center scene, the drawing of lots. The practice of reading lots was never in doubt. The physical objects themselves (sortes) are well known throughout the Italian archaeological record. E.g., a sanctuary at Barbarano, near Padua, yielded 17 such bronze tablets of a shape similar to the one depicted on the Ostian relief (CIL 1 1439-54). At Praeneste (Palestrina), excavators discovered a similar example (CIL 14 2863); see also Wissowa 1912, 258-60. In this regard, the Temple of Hercules at Tibur is a particularly prominent oracular location in literary sources. See Stat. Silv. 1.3.79-80 ("quod ni templa darent alias Tirynthia sortes, / et Praenestinae poterant migrare sorores"); Tib. 2.5.69-70 ("quaeque Aniena sacras Tiburs per flumina sortes, / portarat sicco pertuleratque sinu"). Thus, while I agree that the central scene on the travertine relief does represent the "lots of Hercules" (see, e.g., $R E$ 13:1455-67, s.v. "Lösung") and that the relief itself may inform our understanding of the sanctuary, I believe that Becatti's explication of the narrative is open to challenge. Note that the excavators found no archaeological evidence for oracular practice within the sanctuary at 1.15.5.

${ }^{54} \mathrm{~A}$ hand whose fingers tensely grip a hammer, an arm raised behind the head in the act of striking, and a pair of tongs held in the opposite hand-these, in fact, are the fea-
}

event explaining the importance of his cult at Ostia. ${ }^{55}$ In this respect, the words chiseled on the plaque at the center of the relief may have nothing to do with

tures of Vulcan (LIMC4[1]:627-54, s.v. "Hephaistos"; see also LIMC 4[2]:387, no. 15; LIMC 4[2]:388, no. 46). A marble relief from the Ostian forum depicts Vulcan with these attributes (Ostia, Museo Ostiense, inv. nos. 148, 18853; Berlin, Staatliche Museen, inv. nos. SK912, SK913). For discussion, see Rieger 2004, 223-25. Schefold $(1979,99)$ discusses their provenance. In all these examples, the handheld hammer and the arm prepared to deliver a blow evoke the pose of the figure on the right of the travertine relief. The figure's raised right hand prepares to strike with the hammer while his extended left arm and its tense fist may have gripped a pair of tongs. The drill hole at left may explain where the god's forceps would have been affixed in bronze. That Hephaistos is depicted in a cuirass, similar to the one worn by Hercules at center, is problematic but not entirely without parallel; the god is often depicted in this fashion-albeit on painted pottery-with his hammer and tongs, in scenes depicting the battle of the gods and giants (LIMC 4[2]:139, no. 303; 140-41, no. 312).

${ }^{55}$ As Becatti (1938-1939) noted, the discovery of such a statue from the sea, whether Hercules or Vulcan, would have been an undeniable monstrum (i.e., a sign indicating that the harmony between gods and humans was out of balance); such a monstrum would have required the intervention of a priest, the haruspex, to interpret the sign and propose a proper course of action. On the role of the haruspex in Roman 
Hercules at all; $;{ }^{56}$ they could refer to the establishment of a festival in Vulcan's honor. ${ }^{57}$ In any event, it is important to note that the relief, like the altar on the temple porch, makes no reference to a building of any kind. ${ }^{58}$ In the end, if Bloch's Late Antique inscription did commemorate the restoration of a temple of Hercules at Ostia, the building at 1.15.5, the most ancient temple at Ostia, may not have been it. In fact, it is quite possible, however unlikely, that there may never have been a temple of Hercules at Ostia at all. ${ }^{59}$

\section{The Late Antique Hercules Inscription}

More significant still, there are problems with Bloch's reading of the Hercules inscription. Although he states that "[ $[$ ] ella Herculis is equivalent to templum Herculis," the entire body of Ostian epigraphy offers no support for such an assertion. ${ }^{60}$ Both at Ostia and more widely throughout the Roman world, it is the word aedes, not "cella" or templum, that commonly re-

religion, see, e.g., Cic. Div. 2.41.86; see also Livy 22.1.8-20; Liebeschuetz 1979, 22-3; Beard et al. 1998, 1:19-20, 37-9. In this respect, the scene at the center of the travertine relief may indicate exactly what the haruspex recommended: to bring the matter before a local, oracular shrine of Hercules and thereby to learn more precisely what the gods had portended. Indeed, here, Hercules himself is present, as is the chest of lots; the god holds a plaque and extends it to a sanctuary attendant.

${ }^{56}$ The only text on the relief is the dedicatory inscription, with its deliberately archaic spelling of haruspex ("haruspexs"), and an additional four letters that are chiseled on the plaque in the central scene (AÉpigr 1941, no. 67). A close study of the travertine relief concluded in the fall of 2007 confirmed the difficulty Becatti faced when reading this text. The letters are $1.1 \mathrm{~cm}$ high and, unlike the letters in the dedicatory inscription above, are carved without serifs. No one has ever attempted to explain the slight discrepancy. Becatti $(1938-1939,47)$ himself emended the letters to read: "[S]ORT[ES]•H(ERCULIS)" (the lots of Hercules). This reading of the text seems forced-not least because it assumes the viewer required a textual label to identify the scene. Becatti himself had to supply an "ES" to complete what he thought was a plural word, a form unattested in any of his examples, and there is hardly sufficient space between words to supply two missing letters. He did not offer any explanation for the circumstance that led to missing the first consonant, the "S." And yet, as the relief itself makes clear, the small tablet has neither been broken nor chipped, making the disappearance of its first letter highly unlikely. These circumstances raise the possibility that the word or words on the plaque are not a redundant feature of the image but rather a significant part of the narrative, perhaps even the answer to the oracular consultation.

${ }^{57}$ In preference to Becatti's interpretation of the central letters, I propose to read the text as Greek, not Latin. Zevi has published three bases found in front of the adjacent temple, all of which are inscribed in Greek (Zevi 1963-1964, no. 4009, fig. 71 [Ostia, Museo Ostiense, inv. no. 11664]; Zevi 1969-1970 [Ostia, Museo Ostiense, inv. nos. 11665, 11666]). Indeed, the Greek script used on the statue bases (e.g., Ostia, Museo Ostiense, inv. no. 11666) lacks serifs. It is probable,

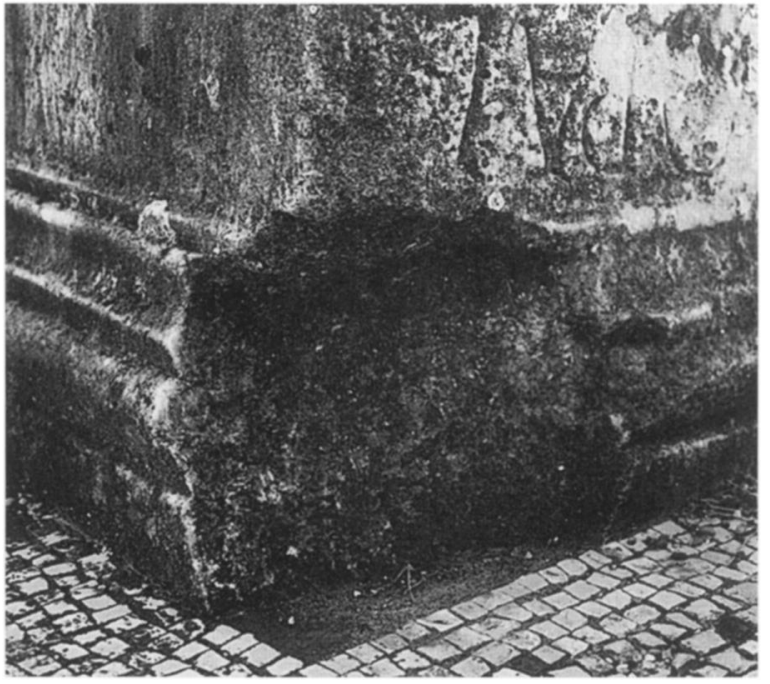

Fig. 6. Rear view of the altar with exposed modern concrete, 2006.

then, that the lack of serifs on the plaque is a visual indication that its text is not written in the same language as the dedicatory inscription above. I suggest that the first word is "OPT $(\mathrm{H})$ "

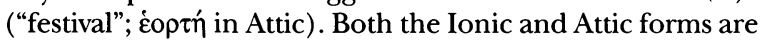

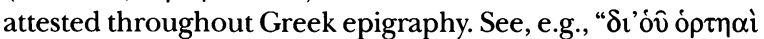

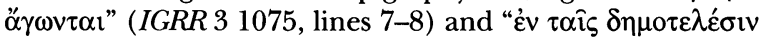

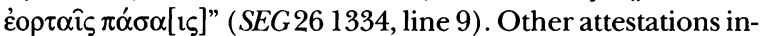
clude IGRR 4 213, 4 294; SEG 40 985. Thus, I complete the text as follows: "OPT $(\mathrm{H}) \cdot \mathrm{H}(\Phi \mathrm{AI} \Sigma \mathrm{TOY})$." Becatti has read a Latin "R" where I have read a Greek "P" (rho). The diagonal stem that forms the descending stroke of the " $R$ " is an illusion, a chip in the travertine, and the first three letters of the text are indeed intact. Only the final "H" (eta) of the first word has been contracted with the first letter of the abbreviated

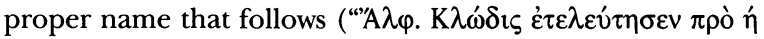

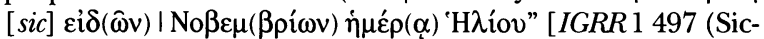

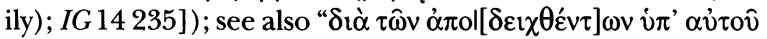

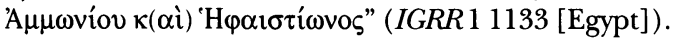

${ }^{58}$ In response to the chance discovery of a statue of Hephaistos (Vulcan), pulled from the sea near Ostia, the oracular Hercules, perhaps at Tivoli, perhaps elsewhere in the vicinity of Rome or its harbor, recommended the establishment of

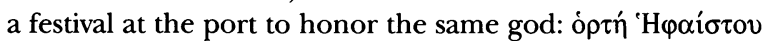
("the festival of Hephaistos").

${ }^{59}$ If I am correct in my identification of the figure and the name of Hephaistos (Vulcan) on the travertine relief, the brick stamps within the cella walls of the temple at 1.15 .5 may provide additional evidence to support my thesis that the building is dedicated to Vulcan (Boin 2009, 52-80). E.g., perhaps not coincidentally, according to the Ostian fasti, on 23 August 112 C.E., Emperor Trajan repaired and rededicated the Ostian Temple of Vulcan, a structure that had been overcome by old age ("aedis Vulkani vetustate corrupta | [restituta or] nato opere, dedicata est" [II 13, lines 45-6]). Bloch, who, following Becatti, believed the temple at 1.15 .5 belonged to Hercules-never noticed the precise correspondence between this epigraphic testimony and the evidence from the brick stamps (102-112 C.E.).

${ }^{60}$ Bloch 1945, 202; he cites only one example from Rome (CIL 62086 ) to bolster his case. 


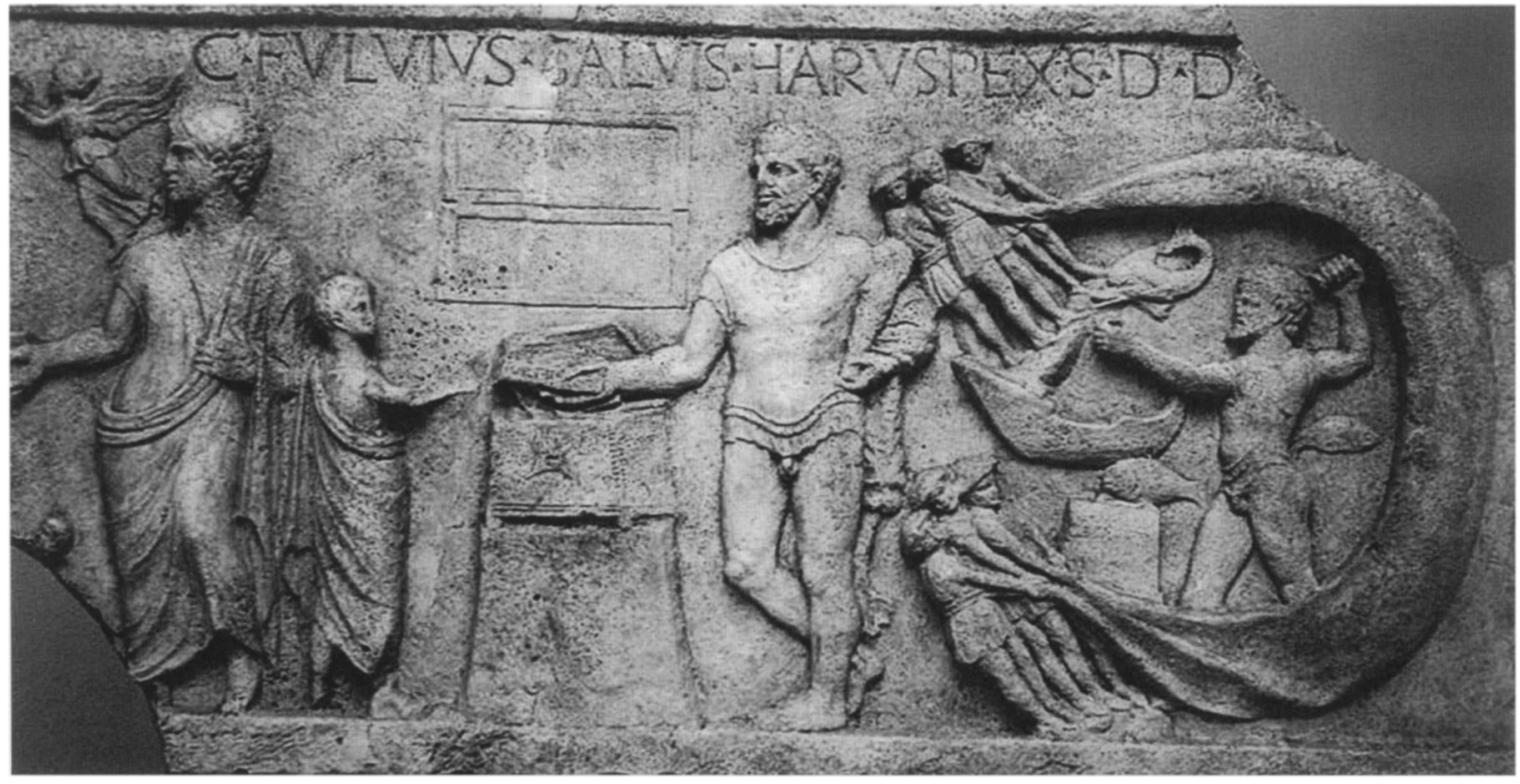

Fig. 7. Travertine relief from the sanctuary, 2007. Ostia, Museo Ostiense, inv. no. 157 (courtesy Soprintendenza per i Beni Archeologici di Ostia).

fers to a sacred building ${ }^{61}$ Multiple examples from Ostia itself confirm that the temples of Vulcan, Roma and Augustus, Venus, Fortuna, Ceres, Spes, Castor and Pollux, and Bona Dea were all aedes. ${ }^{62}$

Furthermore, the Latin text suggests that the inscription may not have commemorated a sacred space. The word "cella," for example, appears most prominently in another Late Antique inscription from Ostia. Its fragments were discovered in $\mathbf{1 7 7 6}$ near the massive structures at 4.10.1-2, known today as the Porta Marina baths (fig. 8) ${ }^{63}$ The text, dated to 377 C.E. on the basis of the prefect's name, ${ }^{64}$ reads as follows: ${ }^{65}$

thermas maritimas intresecus refectione cellarum foris soli adiectione $\mathrm{d}$ [omini]

$\mathrm{n}$ [ostri] Valens Gratianus et Valentinianus victor[es] ac triumpf[atores] semper Au[gusti]

\footnotetext{
${ }^{61}$ Varro Ling. 7.8-10; see also NTDAR 1-2, s.v. "Aedes"; $R E$ 2:5, lines 480-85, s.v. "Templum."

${ }^{62}$ CIL 1473 ("aedis Romae et Augusti"); CIL 14353 ("in aede Romae et Augusti"); CIL 14 375; Thylander 1952, no. B335 ("aedem Volkani, aedem Veneris," "aed[em] Fortuna," "aed[em] Ceres," "aedem Spes"); CIL 14376 ("aedem Castoris et Pollucis, aedem Veneris"); CIL 143530 ("aedem Bonae Deae").

${ }^{63}$ The line of the inscription confirms its connection with a public bath complex along the shore (thermas maritimas), and the Porta Marina bath complex is the only candidate that fits this description. Note that the Italian name terme marittime,
}

\begin{abstract}
Proculo Gregorio v(iro) c(larissimo) praefecto annon[ae] urbis Romae curante decorarunt
\end{abstract}

Our lords, Valens, Gratian and Valentinian I, victors, triumphant and forever emperors-under the supervision of the Prefect of the Grain of the city of Rome, Proculus Gregorius, vir clarissimus-decorated the Maritime Baths by repairing the halls on the inside [and] by adding [space] outside for the sun.

It is important to note that the word "cella" is used here without any reference to a sacred structure. In fact, it is a word that indicates a functional space within the bath complex, a gathering "hall" or perhaps a utilitarian "storeroom." ${ }^{66}$ Comparative epigraphic and literary evidence suggests this reading is the correct one. Pliny the Younger, referring to his own private

which Visconti bestowed on an entirely separate set of bath structures at 3.8.2 in the 19th century, is misleading. These buildings were positioned ca. $100 \mathrm{~m}$ from the ancient shore, and none of them shows any indication of fourth-century restoration (Meiggs 1973, 407-8).

${ }^{64} \mathrm{Cod}$. Theod. 14.3.15. Symmachus also wrote a letter to a Gregorius, whether the same man or not is uncertain (Ep. 3.17-22); see also Lenski 2002, 320-67.

${ }^{65}$ CIL 14 137; ILS 5694.

${ }^{66}$ See TLL 3:759-61, s.v. "cella." For epigraphic uses of "cella" as a utilitarian room or warehouse, see LTUR 1:256, s.v. “cella Civiciana”; 1:257, s.v. "cella Lucceiana." 
bath complexes, described two of these rooms as cellae. ${ }^{67} \mathrm{~A}$ late second-century inscription from Lanuvium also testifies to the use of the word within the context of bath restorations. ${ }^{68}$ A passage in the Scriptores Historiae Augustae uses the term as well, describing a room in a bath complex whose ceiling may have been gilded with copper or bronze (cellam solerarem) ${ }^{69}$ Although the precise interpretation of this phrase puzzles architectural historians, DeLaine has recently proposed that the term may be a synonym for caldarium. ${ }^{70} \mathrm{Her}$ epigraphic survey revealed other instances of the same word in the restoration of the so-called Large Baths at Mdaourouch, Algeria (Roman Madaurus) ${ }^{71}$ In sum, the material and textual evidence suggests that the word "cella," when used epigraphically, denotes not a temple building or sanctuary space but rather a generic room, perhaps one located in a city bath complex. ${ }^{72}$

Because baths at Ostia remained popular structures for residents and visitors into late antiquity, I would tentatively propose that the Late Antique Hercules inscription came from one such structure, perhaps the nearby Forum Baths or maybe even baths at the Porta Marina gate. ${ }^{73}$ It was at this latter site, in fact, that the Scottish painter Gavin Hamilton found four statues of the labors of Hercules in the $1770 \mathrm{~s} .{ }^{74}$ Indeed, these statues, now in the Vatican, may have once decorated a hall, or cella, of the Late Antique structure. ${ }^{75} \mathrm{Just}$ as

${ }^{67}$ Pliny Ep. 2.17.11, 2.6.25 ("cella frigidaria"). My thanks to Alan Cameron, not only for sharing his forthcoming work on the so-called last pagans of Rome but also for furnishing these epistolary references.

68 " $[\mathrm{A}] \mathrm{mpliatis}$ locis et cellis a fundamentis exstructae et dedicatae" (CIL 14 2101).

69 “[O]pera Romae reliquit thermas nominis sui eximias, quarum cellam solearem architecti negant posse ulla imitatione, qua[lis] facta est, fieri" (SHA M. Ant. 9.4).

${ }^{70}$ DeLaine 1987, 150-55.

71 " [P] ro tanta felicitate tempo[rum invictissi]morum principium dd. nn. per[pp. augg. Valenti]niani et Valentis piscinalem istam ... et soliarem cellam lacuniis densis ita foe[datas ut ima pavi]menti monstrarent, atque ita retentione[m caloris prohi]berent, compellente religione sancta et [utilitate roma]norum civium, exquisitis diversorum co[lorum marmoribus] artificibus quoque peregrines adductis et [adhibitis splen]dentes, novoque omnino opere tes[s]ellatus pr[oconsulatu Jul. Festi cum] Fabio Fabiano v. c. et inlustre legato Numid[iae ... .] cur rei publicae inter cetera in quibus iamdu[dum patriae contuilt] cum ordine splendido et universo popu[lo Madaur. restituit] felicit[er]" (AÉpigr 1907, 237 [the so-called Large Baths, Mdaourouch, 366-367 C.E.]). A second inscription from Thuburnica, Tunisia, which also features the word "cella," is of unknown provenance ("us cellam soliarem a [fundamentis] ... [extru]ctam karissimis [sic] civibus" [CIL 8 10607]).

${ }^{72}$ Lavan (pers. comm. 2009) has suggested that the word "cella" may have been used in connection with the Ostian Capitolium. A highly fragmentary inscription from Abthugni

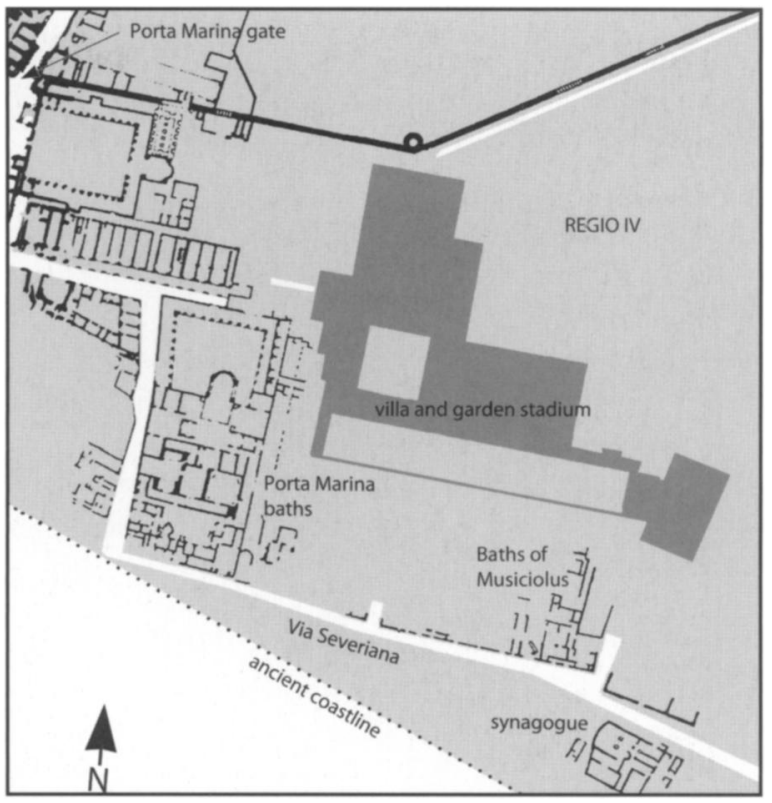

Fig. 8. Plan of Ostia's ancient coastline and the location of the Porta Marina baths (courtesy L.M. White and the Ostia Synagogue Area Project, the University of Texas at Austin).

they had for centuries, representations of Hercules and his labors remained popular subjects for bath complexes throughout late antiquity. ${ }^{76}$ Like mytho-

(modern Henchir es-Souar in Tunisia), dated 383-392 C.E. ("in cellis capi[tolii]" [CIL 8 11205, line 3; 8 928]) seems to support this hypothesis, although both the reading and the restoration of the text are far from certain (Lepelley 1981, 2:265-68).

${ }^{73}$ On baths and bathing, see Fagan 1999, 289-99; see also Arthur (1999) for an example of a fifth-century bath complex in Naples and Mazor (1999) for a contemporary bath complex at Bet She'an. On Ostia, in particular, see Zevi 1971, Poccardi 2001, Spurza 2010.

${ }^{74}$ Hamilton and Smith 1906; see also Deutsches Archäologisches Institut, Rome, negs. 769, 1104, 1107, 1121; Vatican City, Vatican Museums, inv. nos. 402, 405, 488, 492.

${ }^{75}$ This thesis may help other scholars interpret the only other use of the word "cella" at Ostia (CIL 14 376). This inscription records the restoration of a cellam patri Tiberino, a structure that no scholar has yet convincingly identified at Ostia. If one takes into account, however, that the very next line of the inscription reports that "the same man restored the baths, which Divine Antoninus Pius had built," it is possible that these baths, too, contained a "hall" once renowned and named for the aesthetic themes displayed therein.

${ }^{76}$ Manderscheid 1981, 33-4. Most of the Hercules statues and statuettes have been found in frigidaria throughout imperial bath complexes. Several of these examples date to late antiquity: Manderscheid 1981, no. 16 (Aix-les-Bains), no. 51 (Rome); see also no. 141 (Argos), no. 179 (Ephesos), no. 76 (statuette found in the Forum Baths at Ostia), nos. 347, 360, $407,465,489,530$ (from cities in North Africa). 
logical tales of Phaedra and Hippolytus, Theseus, Ariadne, or Dionysos, which were frequently represented across the western and eastern empires in mosaics, statuary, and objets d'art, the stories of Hercules remained important subjects, especially for those desirous of advertising their educated pedigree. ${ }^{77}$ It is not surprising, then, that public venues such as imperial bath complexes would have continued to serve as both staging ground and backdrop for traditional displays of civic benefaction, imperial largess, and mythological subject matter. ${ }^{73}$ This kind of urban development accords well with contemporary archaeological evidence in Rome, Constantinople, and other cities of the Late Roman empire. ${ }^{79}$

\section{CONCLUSION}

Thus, rather than interpreting the Late Antique Hercules inscription from Ostia as a unique document in the narrative of the late fourth century, I suggest it is one more display, on a local level, of a wider cultural concern for urban display and civic upkeep that characterized this period of transformation. This repair to one of the bath complexes thereby took place independently of the revolt in 393-394 C.E. and suggests that the Hercules evidence is a shaky, if not misplaced, building block on which to base the purported religious motives of Eugenius' late fourth-century usurpation. ${ }^{80}$ Indeed, the balance of the textual and material evidence confirms the lasting presence that traditional religious spaces held at Ostia throughout the period of ascendant Christianity, even as public sacrifices gradually came to an end. ${ }^{81}$ The sanctuary at 1.15 .5 , the attribution of which remains unclear, was one of those historic sites. Its repair in the late fourth or early fifth century, irrespective of religious sentiment, and the simultaneous concern evinced elsewhere for other sacred sites in Ostia speak to the collective role that temples and sanctuaries played as lieux de mémoire throughout the town. ${ }^{82}$ Encouraging the formation of

\footnotetext{
${ }^{77}$ Thus, consider the fifth-century Hercules panels on fabric, now in Russia (Exposition sur les Trésors de l'Art Copte 2001, no. 149), and the fifth-century sculpted relief of Hercules strangling the Nemean lion from Ahnas el-Medineh (Heraclepolois Magna [Exposition sur les Trésors de l'Art Copte 2001, no. 150]). More generally, see Bowersock 2006, 31-64.

${ }^{78}$ See Lenski 2002, 393-401, appx. D ("Civic Structures Built under Imperial Sponsorship, A.D. 364-378”).

${ }^{79}$ E.g., on the Baths of Zeuxippus in Constantinople, see Bassett 2004. For more general introductions to Late Antique urbanism, see also Wharton 1995; Bauer 1996. On the continued educational and social relevance of mythological subjects such as the labors of Hercules, see also Cameron 2004; Bowersock 2006

${ }^{80}$ It may be true, if we accept Christian sources, that in 394 the usurper Eugenius marched against Theodosius under the
}

layered identities through a respect for history and new traditions, this archaeological context cautions against any further attempt to frame the fourth century in terms of "triumph" and "revival" or as one easily divided between "pagan" and "Christian."

DEPARTMENT OF CLASSICS

UNIVERSITY OF TEXAS AT AUSTIN

AUSTIN, TEXAS 78712

DRBOIN@MAIL.UTEXAS.EDU

\section{Works Cited}

Arthur, P. 1999. "The 'Byzantine' Baths at Santa Chiara, Naples." In Roman Baths and Bathing, edited byJ. DeLaine and D.E. Johnston, 135-46. JRA Suppl. 37. Portsmouth, R.I.: Journal of Roman Archaeology.

Bakker, J.T. 1994. Living and Workingwith the Gods: Studies of Evidence for Private Religion and Its MaterialEnvironment in Ostia (100 B.C.-500 A.D.). Amsterdam: J.C. Gieben.

Bassett, S. 2004. The Urban Image of Late Antique Constantinople. Cambridge: Cambridge University Press.

Bauer, F.A. 1996. Stadt, Platz und Denkmal in der Spätantike. Mainz: Philipp von Zabern.

. 2003. "Stadtbild und Heiligenlegende: Die Christianisierung Ostias in der spätantiken Gedankenwelt.” In Die spätantike Stadt und ihre Christianisierung, edited by G. Brands and H.G. Severin, 43-62. Wiesbaden: Reichert.

Bauer, F.A., and C. Witschel, eds. 2007. Statuen in der Spätantike. Wiesbaden: Reichert Verlag.

Beard, M., J. North, and S. Price. 1998. Religions of Rome. 2 vols. Cambridge: Cambridge University Press.

Becatti, G. 1938-1939. "Il culto di Ercole ad Ostia." BullCom 67:37-60.

1942. "Nuovo documento del culto di Ercole ad Ostia." BullCom 70:115-25.

Bignamini, I. 2001. "Histoire de la découverte et de la recherche du Moyen Age à 1800.” In Ostia: Port et Porte de la Rome antique, edited by J.-P. Descoeudres, 41-7. Geneva: Musées d'Art et d'Histoire.

Bloch, H. 1945. "A New Document in the Last Pagan Revival in the West, 393-394 A.D." HTR 38:199-244.

. 1963. "The Pagan Revival in the West at the End of the Fourth Century." In The Conflict Between Paganism

standards of both Hercules and Jupiter (Theodoret Hist. eccl. 5.24.4-17; Patrologia Graeca 82, col. 1250-54; see also August. De civ. D. 5.26). However, it is worth remembering that by the late fourth century, these two gods had long been associated with the Roman emperors of the tetrarchy (Augusti). For numismatic evidence, see also MacCormack 1981; her discussion of the Arch of Galerius at Thessaloniki is also particularly illustrative (MacCormack 1981, 31, 127-29).

${ }^{81}$ On Christian Ostia, see, e.g., Bauer 2003; Boin (forthcoming [a]).

${ }^{82}$ Without intending to exhaust the subject here, I borrow the phrase from Nora (1996, 1:1-20). My monograph (Boin [forthcoming (b) ]) will treat this topic in more detail. For an extensive bibliography on the role of memory in historical studies, see Galinsky 2009. 
and Christianity in the Fourth Century, edited by A. Momigliano, 193-218. Oxford: Clarendon Press.

Boin, D.R. 2007. "The Transformative Powers of Religion in the Late Antique Landscape of Ostia." Paper read at "Shifting Frontiers VII: The Power of Religion in Late Antiquity," 22-25 March, Boulder, Colo.

. 2009. "Temples and Traditions in Late Antique Ostia, c. 250-700 C.E." Ph.D. diss., the University of Texas at Austin.

—. Forthcoming (a). "Late Antique Ostia and a Campaign for Pious Tourism: Epitaphs for Bishop Cyriacus and Monica, Mother of Augustine." JRS 100.

- Forthcoming (b). A Social History of the Religious Landscape in Late Antique Ostia.

Bowersock, G. 1978. Julian the Apostate. Cambridge, Mass.: Harvard University Press.

- 2006. Mosaics as History: The Near East from Late Antiquity to Islam. Cambridge, Mass.: Harvard University Press.

Bradbury, S. 1995. "Julian's Pagan Revival and the Decline of Blood Sacrifice." Phoenix 49:331-56.

Brenk, B. 2005. Architettura e immagini del sacro nella tarda antichità. Spoleto: Fondazione Centro Italiano Studi sull'Altro Medioevo.

Calza, G. 1938. "La resurrezione di Ostia antica per l'Esposizione Universale di Roma." Gnomon 14(11): 605-8.

- ed. 1954. Topografia generale. Scavi di Ostia 1. Rome: Istituto Poligrafico dello Stato.

Cameron, Alan. 1966. "The Date and Identity of Macrobius." JRS 56:25-38.

— 1999. "The Last Pagans of Rome." In The Transformations of Urbs Roma in Late Antiquity, edited by W. Harris, 109-121. JRA Suppl. 33. Portsmouth, R.I.: Journal of Roman Archaeology.

. 2004. Greek Mythography in the Roman World. Oxford: Oxford University Press.

Cameron, Averil. 1993. The Later Roman Empire, A.D. 284430. Cambridge: Fontana.

Coarelli, F. 1998. Il foro boario: Dalle origini alla fine della repubblica. Rome: Quasar.

Croke, B., and J. Harries. 1982. Religious Conflict in Fourth Century Rome: A Documentary Study. Sydney: Sydney University Press.

DeLaine, J. 1987. "The 'Cella Solearis' of the Baths of Caracalla: A Reappraisal.” PBSR 55:147-55.

Drake, H.A. 2000. Constantine and the Bishops: The Politics of Intolerance. Baltimore: The Johns Hopkins University Press.

Ebbeler, J., and C. Sogno. 2007. "Religious Identity and the Politics of Patronage: Symmachus and Augustine." Historia 56:230-42.

Elsner, J. 2000. "From the Culture of Spolia to the Cult of Relics: The Arch of Constantine and the Genesis of Late Antique Forms." PBSR 68:149-84.

Ensoli, S., and E. La Rocca, eds. 2000. Aurea Roma: Dalla città pagana alla città cristiana. Rome: L'Erma di Bretschneider.

Exposition sur les Trésors de l'Art Copte. 2001. L'art copte en Égypte: 2000 ans de christianisme (Exposition présentée à l'Institut du Monde Arabe, Paris, du 15 maiau 3 septembre 2000 et au Musée de l'Ephèbe au Cap d'Agde, du 30 septembre 2000 au 7 janvier 2001). Paris: Institute du Monde Arabe.

Fagan, G. 1999. Bathing in Public in the Roman World. Ann Arbor: University of Michigan Press.
Galinsky, K. 2009. Memoria Romana Project. https://www. utexas.edu/research/memoria (21 September 2009).

Gering, A. 2004. "Plätze und Straßensperren an Promenaden:Zum Funktionswandel Ostias in der Spätantike.” RM 111:299-382.

Hamilton, G.J., and A.H. Smith. 1906. "Gavin Hamilton's Letters to Charles Townley." JHS 21:306-21.

Hedrick, C. 2000. History and Silence: Purge and Rehabilitation of Memory in Late Antiquity. Austin: The University of Texas Press.

Heinzelmann, M. 2001. “Ostia, Regio III: Untersuchengen in den unausgegrabenen Bereichen des Stadtgebietes Vorbericht zur dritten Grabungskampagne 2000.” RM 108: 313-28.

- 2002. "Ostia, Regionen III und IV: Untersuchungen in den unausgegrabenen Bereichen des Stadtgebietes." RM 109:225-42.

Heres, T.L. 1982. Paries: A Proposal for a Dating System of Late Antique Masonry Structures in Rome and Ostia A.D. 235-600. Amsterdam: Rodopi.

Jones, A.H.M. 1966. The Decline of the Ancient World. London: Longmans.

Jones, A.H.M., J.R. Martindale, and J. Morris. 1971. The Prosopography of the Later Roman Empire. Cambridge: Cambridge University Press.

Laird, M. 2000. "Reconsidering the So-Called 'Sede degli Augustali' at Ostia." MAAR 45:41-84.

Lavan, L., and A. Gering. 2009. Kent-Berling Ostia Excavations. http://ateantiqueostia.wordpress.com (21 September 2009).

Lenski, N. 2002. Failure of Empire: Valens and the Roman State in the Fourth Century A.D. Berkeley: University of California Press.

— ed. 2006. The Cambridge Companion to the Age of Constantine. Cambridge: Cambridge University Press.

Lepelley, C. 1981. Les cités de l'Afríque romaine au bas-empire. 2 vols. Paris: Études Augustiniennes.

Liebeschuetz, J.H.W.G. 1979. Continuity and Change in Roman Religion. Oxford: Clarendon Press.

MacCormack, S. 1981. Art and Ceremony in Late Antiquity. Berkeley: University of California Press.

Manderscheid, H. 1981. Die Skulpturenausstattung derkaiserzeitlichen Thermenanlagen. Berlin: Main Verlag.

Mar, R. 1990. "El santuario de Hércules y la urbanística de Ostia." ArchEspArq 63:137-60.

_ 1992. "El teatro de Tarragona y el santuario di Hercules en Ostia: Dos elementos en la tranformación de las cuidades del occidente romano durante los siglos II y III d.C." In Die römische Stadt im 2. Jahrhundert n. Chr: Der Funktionswandel des öffentlichen Raumes, 163-81. Cologne: Rheinland Verlag.

Marchesini, R. 2004-2005. "Il tempio di Vulcano ad Ostia." Ph.D. diss., Università degli Studi di Roma "La Sapienza."

Matthews, J. 1989. The Roman Empire of Ammianus. London: Duckworth.

. 2000. Laying Down the Law: A Study of the Theodosian Code. New Haven: Yale University Press.

Mazor, G. 1999. "Public Baths in Roman and Byzantine Nysa-Scythopolis (Bet She'an).” In Roman Baths and Bathing, edited by J. DeLaine and D.E. Johnston, 293302. JRA Suppl. 37. Portsmouth, R.I.: Journal of Roman Archaeology.

McLynn, N. 1994. Ambrose of Milan. Berkeley: University of California Press. 
Meiggs, R. 1973. Roman Ostia. 2nd ed. Oxford: Oxford University Press.

Meneghini, R. 2003. "La trasformazione dello spazio pubblico a Roma tra tarda antichità e alto medioevo." $M E ́-$ FRA 115:1049-62.

Muntasser, N. 2003. "The Late Antique Domus in Ostia: Patterns of Diversity and Transformation." Ph.D. diss., the University of Texas at Austin.

Nora, P. 1996. Lieux de mémoire/Realms of Memory: Rethinking the French Past. Translated by A. Goldhammer. 3 vols. New York: Columbia University Press.

O’Donnell, J.J. 1977. "Paganus." Classical Folia 31:16369.

. 2005. Augustine: A New Biography. New York: Harper Collins.

Olivanti, P. 2002. "Dante Vaglieri alla direzione degli scavi di Ostia Antica (1908-1913): Da documenti dell'Archivio Storico della Soprintendenza di Ostia." ActaInstRomFin 27:271-89.

Paroli, L. 1993. "Ostia nella tarda antichità e nell'alto medioevo." In La stora economica di Roma nell'alto medioevo alla luce dei recenti scavi archeologici, edited by L. Paroli and P. Delogu, 153-75. Florence: Edizioni all'Insegna del Giglio.

Paschetto, L. 1912. Ostia colonia romana: Storia e monumenti. Rome: Tipografia Poliglotta Vaticana.

Picard, G.C. 1976. "La statue du temple d'Hercule à Ostia." In In Memoriam Otto J. Brendel: Essays in Archaeology and the Humanities, edited by L. Bonfante and $\mathrm{H}$. von Heintze, 121-29. Mainz: Philipp von Zabern.

Poccardi, G. 2001. "Thermes et bains de l'Ostie antique." In Ostia: Port et Porte de la Rome antique, edited by J.-P. Descoeudres, 161-71. Geneva: Musées d'Art et d'Histoire.

Rieger, K. 2001. "Les sanctuaires publics à Ostie de la République jusqu'au Haut Empire." In Ostia: Port et Porte de la Rome antique, edited by J.-P. Descoeudres, 247-61. Geneva: Musées d'Art et d'Histoire.
2004. Heiligtümer in Ostia (Studien zur antiken Stadt 8). Munich: Verlag Dr. Friedrich Pfeil.

Rose, H.J. 1933. "The Cult of Vulkanus at Rome." JRS 23: 46-63.

Salzman, M. 1990. On Roman Time: The Codex-Calendar of 354 and the Rhythms of Urban Life in Late Antiquity. Berkeley: University of California Press.

Schefold, K. 1979. “Athenas und Hephaistos' Leben auf einem Fries in Ostia und Berlin.” AntK 22:99-103.

Seeck, O. 1919. Regesten der Kaiser und Päpste fur der Jahre 311 bis 476 n. Chr. Stuttgart: Metzler.

Sogno, C. 2006. Q. Aurelius Symmachus: A Political Biography. Ann Arbor: University of Michigan Press.

Spurza, J. 2010. “'Tenacious Baths' at Later Ostia: Excavation of the Palazzo Imperiale, 2009." Paper read at the 2010 Annual Meeting of the Archaeological Institute of America, 6-9 January, Anaheim.

Taylor, L.R. 1912. The Cults of Ostia. Bryn Mawr: Bryn Mawr College.

Thylander, H. 1952. Les inscritpions du port d'Ostia. Lund: Gleerup.

Tione, R. 1999. "Le domus tardoantiche: Nuovi elementi per l'interpretazione dell'edilizia abitativa attraverso la lettura stratigrafica degli elevati." Meded 58:191-208.

Wharton, A.J. 1995. Reconfiguring the Post Classical City: Dura Europos, Jerash, Jerusalem and Ravenna. Cambridge: Cambridge University Press.

Wissowa, G. 1912. Religion und Kultus der Römer. Munich: C.H. Beck.

Zevi, F. 1963-1964. "Base di una statua di Platone il commediografo rinvenuta ad Ostia." FA 18-19:291-92.

. 1969-1970. "Tre iscrizioni con firme di artisti greci: Saggi nel tempio dell'ara rotonda a Ostia." RendPont Acc 42:95-116.

1971. "Miscellanea ostiense: II. Hostilius Antipater, prefettto dell'annona.” RendLinc 26:468-72. 